\title{
People's Behavior of Online Banking and its Influencing Factors
}

\author{
Jiani Zhan ${ }^{1, a}$, Weilun Huang ${ }^{1, b, *}$ \\ ${ }^{1}$ School of Finance, Wenzhou Business College, China \\ a735803358@qq.com, bhuangwl@wzbc.edu.cn \\ ${ }^{*}$ Corresponding author
}

Keywords: Online Banking; Chinese people's behavior; Influencing Factors

\begin{abstract}
The scale of online banking is developing rapidly nowadays, but there are still few relevant literatures about people's behavior of online banking. Therefore, the purpose of this paper is to analyze the Chinese people's behavior of online banking and its influencing factors, based on the review of literatures and the survey of questionnaires. According to the results of the questionnaires, it could be found that the online banking amount and frequency of Chinese people are less than other online payments. For example, their average online banking amount is RMB 2,301.59/month, and their average frequency is 3.81 times/month. Moreover, its influencing factors discussed in this paper are significantly positively influencing people's behavior of online banking, which are its cognitions of financial advantage, its perceived usefulness, its cognitions of platform convenience, and its cognitions of platform risk are significantly negatively. Individual variables (gender, monthly income, used platform) of people who use online banking have a significant impact on their behavior of online banking and its influencing factors.
\end{abstract}

\section{Introduction}

With the development of information technology and the changes of the financial environment, online banking has become the main business to develop for the commercial banks, but there are not many literatures related to people's behavior of it. Therefore, the research objects of this paper are people's behavior of online banking and its influencing factors, and then provide policy reference for government and bankers. The definition of online banking is the financial services that commercial banks provide to customers by internet, including basic banking services, deposits, the transactions of stock and bond, consumer and student loans, electronic billing, and international payments. Ramsey (2014) found that the advantage of online banking is to reduce the trading risk which caused by its information asymmetry. Ozdemir and Trott (2009) found that the influencing factors of online banking are risk and technology. Meyer (2006), Hernandez and Mazzon (2007), and Sayar and Wolfe (2007) found that the online banking frequencies of people in Europe and Brazil are directly proportional to their information technology capabilities.

The first online bank was established in the United States in 1995. China's online banking continued to follow up. Today, commercial banks in many countries have developed this business. Analysys (2018) found that the online banking volume of China in the first quarter of 2018 was RMB 453.60 trillion (its annual growth rate of 7.60\%), and Industrial and Commercial Bank of China, China Construction Bank and Bank of Communications had the top three market shares in 2018 of China. Unyathanakorn and Rompho (2014) found that the top six banks on the market shares of online banking in 2011 of Thailand were Siam Commercial Bank, Kasikorn Thai Bank, Bangkok Bank, Krung Thai Bank, Bank of Ayudhya, and Thai Military Bank (the market share was 83.22\%). Mattila, et al. (2003) pointed out that the penetration rate of Finnish online banking is the highest in the world (about 64\%). The users of the bank with largest online banking market share (Nordea) is exceeded 1.4 million.

According to the literature, the influencing factors of people's behavior of online banking can be divided into its cognitions of financial advantage, its perceived usefulness, its cognitions of platform 
convenience, and its cognitions of platform risk. Specifically speaking, its cognitions of financial advantage are that banks would possess large capital and high supervision. Its perceived usefulness includes the information protection, convenience, versatility, and attractiveness of online banking. Its cognitions of platform convenience are the freedom of time and place, diverse services, flexibility, and mature risk control of online banking. And its cognitions of platform risk risks refer to credit risk, privacy risk, operational risk, fraud risk of online banking. Shen (2015) believes that online banking should be the main business of commercial banks which have stronger and better capability of risk control compared with other new financial institutions. Xing (2001), Flavian, et al. (2006) and Lichtenstein and Williamson (2006) argue that online banking is free on time and place to use. Aderonke and Charles (2010) found that the reasons for using online banking are the convenience, ease of use, and time savings. Liu (2018) believes that the resources of operational risks of Chinese online banking can be divided into clients, bank personnel, and systems. Kim, et al. (2010) and Sathye (1999) argue that online banking risk is the security risk. Li, et al. (2012) believe that the privacy risks of online banking include its information disclosure, fund theft, technology risks.

According to the above discussion, this paper would study people's behavior of online banking and its influencing factors, and also explore the impact of people's individual variables which are their gender, age, monthly income, and used platform on the above-mentioned behaviors and influencing factors. Flavian, et al. (2006) found that income, age, gender, and trust of people should be the factors influencing people's behavior of online banking. Sun (2007) found that the most of users would choose online banking services provided by state-owned commercial banks. In addition to the introduction, this article is divided into the following sections: the second part is the review of literatures which are discussed people's behavior of online banking and its influencing factors, the third part is the analysis of questionnaire, and the fourth part is the conclusion and suggestion.

\section{The Review of Literatures}

From the sorting results of Chinese literatures, online banking should be a vital research topic, and there are still few literatures on people's behavior of online banking and its influencing factors. The topics of the existing research on online banking are its development status, advantages and disadvantages, risk supervision, and etc.. Among them, the online banking (in the title) first appeared in 1981, most in 2001, and achieved 4,413 articles as of September 27, 2018. There is no literature on people's behavior of online banking (in the title). A similar topic is the survey and analysis on people's willingness, intention or preference of online banking (a total of 23 articles), there are 14 papers on the influencing factors of online banking (in the title), and most of their research topics are risk cognition and operational risk of online banking. According to the results of literature review, it can also be found that people's cognitions of financial advantage, people's perceived usefulness, people's cognitions of platform convenience, and people's cognitions of platform risk on online banking are often taken as factors influencing people's behavior of online banking.

Referring to the literature, this paper defines people's behavior of online banking and its influencing factors as: the parameters of people's behavior of online banking are the online banking frequency and amount which used by respondents. For example, Li, et al. (2012) regard people's behavior of online banking as its frequency. Sun (2007) regards their transaction amount as people's behavior of online banking.

The parameters, people's cognitions of financial advantage on online banking, are defined as strong capital, normative supervision, novel interface layout, and information transparency of online banking. Shih and Fang (2003) believe that the perceived advantages of online banking is the influencing factor of people's intention.

The parameters on people's perceived usefulness of online banking are defined as the account security, ease of use, and versatility of online banking. Eriksson, et al. (2005) point out that the perceived usefulness of online banking means that it can increase the customer's understanding of its financial situation and banking. Safeena, et al. (2010) and Alsajjan and Dennis (2010) point out that 
the perceived usefulness of online banking refers to the awareness of diversified online banking services.

The parameters on people's cognitions of platform convenience of online banking are the freedom of time and place, flexibility, and solid risk control of online banking. Tao (2010) points out that the convenience of online banking is no geographical restrictions and time constraints. Jalal, et al. (2011) suggests that its platform convenience means that online banking is more acceptable than other financial services. Aderonke and Charles (2010) argue that its platform convenience refers to the usefulness, convenience, and ease of people's behavior of online banking.

The parameters on people's cognitions of platform risk are the credit risk, privacy risk, operational risk and fraud risk of online banking. Poon (2008) suggests that the risks of online banking are its privacy and security risks. Wang (2012) believes that the influencing factors of online banking users' intentions are its privacy agreements and customer trust. Tang and Zhang (2012) point out that the important influencing factors of operational risk are personnel, internal control, corporate governance structure, banking supervision and financial corruption of online banking.

Respondents' individual parameters are defined as their gender, monthly income, and used platform. Liu and Qin (2016), Hassanuddin, et al. (2012) indicated that women are significantly more risk-averse than men. Li, et al. (2012) point out that the amount of online banking is related to its function. Eriksson, et al. (2005) thought that people's behavior of online banking is related to its gender and monthly income.

\section{The Analysis of Questionnaire}

The questionnaire was conducted online in China from June 15 to June 21, 2018, and its number was 567. The statistical results of the respondents' individual parameters are: (1) Gender: males of the respondents accounted for $60.85 \%$, while women accounted for $39.15 \%$. (2) Monthly income: The average monthly income of respondents was RMB 4,193.12 (standard deviation was 1,114.16). (3) Used platforms: The platform used by the $40.74 \%$, 39.68\%, 37.92\%, 32.10\%, and $31.39 \%$ of the respondents were respectively online banking of China Construction Bank, Industrial and Commercial Bank of China, Agricultural Bank of China, Bank of China. In addition, each person used about two platforms on average.

The descriptive statistics results of people's behavior of online banking are as follow: the average online banking frequency of respondents was 3.81 times/month (standard deviation is 3.43), and the average online banking number of respondents was RMB 2,301.59/month (standard deviation is 1,956.65).

The descriptive statistics results of the influencing factors on people's online banking behavior are: respondents had the highest degree of approval for their cognitions of platform risk, but the lowest for their perceived usefulness. In terms of their cognitions of financial advantage, respondents most agreed that online banking had strong capital, followed by strict supervision and normative operation. For their cognitions of perceived usefulness, respondents most agreed with the information protection of online banking. For their cognitions of platform convenience, respondents most agreed with the diversity of usage services of online banking. When it came to their cognitions of platform risk, respondents most agreed with the risk of fraud on the online banking platform.

The results of the variance analysis on people's behavior of online banking and its influencing factors are shown in Table 1, from which we can see that the significant influencing factors are its cognitions of financial advantage, its perceived usefulness, its cognitions of platform convenience, and its cognitions of platform risk. Among them, the first three are positive significant influence factors, while the last one is negative. 
Table 1. The Results of the Variance Analysis of People’s Behavior of Online Banking and its Influencing Factors

\begin{tabular}{|c|c|c|c|}
\hline \multirow{2}{*}{} & \multicolumn{2}{c|}{ People's Behavior } \\
\cline { 3 - 4 } & Its Cognitions of Financial Advantage & $463.85^{* * 8}$ & Frequency \\
\hline \multirow{3}{*}{ Factors } & Its Perceived usefulness & $463.79^{* * 8}$ & $3,333.38^{* * *}$ \\
\cline { 2 - 4 } & Its Cognitions of Platform Convenience & $430.64^{* * 8}$ & $2,396.08^{* * *}$ \\
\cline { 2 - 4 } & Its Cognitions of Platform Risk & $345.07^{* * 8}$ & $1,337.15^{* * *}$ \\
\hline
\end{tabular}

In order to further understand the results of the questionnaire, this paper explores the impact of individual variables of respondents on people's behavior of online banking and its influencing factors. We sort out the hypothesis verification results on the individual variables of respondents are shown in Table 2. From Table 2, the impact of gender and monthly income of respondents is significant. For example, the average online banking frequency of male respondents are 1.67 times more than females per month, and the average online banking amount of male respondents are RMB 984.26 more than female respondents per month. And the higher income respondents got, the more remarkable of people's behavior (higher amount and frequency). Moreover, male respondents or those with higher monthly incomes were more likely to agree with online banking financial advantage, perceived usefulness, and platform convenience cognition than other groups, but their approval for platform risk cognition was significantly lower than other groups.

It can be seen from Table 2 that whether the respondents use the platform (CCB, ICBC, ACB) has a significant impact on the influencing factors of people's behavior of online banking, but the impact of the platform (BOC) is insignificant. For example, respondents who utilized the platform (CCB, ICBC, ACB) transacted RMB 1,573.06, 1,367.90, and 1,158.71 more than those didn't, respectively. Moreover, their average online banking frequency was 2.90 times, 2.67 times, and 2.40 times more than the respondents who didn't use those platforms. Except the above, respondents with used platform had a greater degree of approval for financial superiority, perceived usefulness, and platform convenience than those who do not, but opposite for platform risk.

Table 2. Hypothesis Verification of individual variables of Respondents for People's Behavior of Online Banking and its Influencing factors

\begin{tabular}{|c|c|c|c|c|c|}
\hline \multirow{2}{*}{$\begin{array}{l}\text { Gender } \\
\mathrm{F}(\mathrm{t})\end{array}$} & \multirow{2}{*}{$\begin{array}{c}\text { Monthly } \\
\text { income } \\
\text { F }\end{array}$} & \multicolumn{4}{|c|}{ Used platform } \\
\hline & & $\begin{array}{r}\mathrm{ABC} \\
\mathrm{F}(\mathrm{t})\end{array}$ & $\begin{array}{l}\text { ICBC } \\
\mathrm{F}(\mathrm{t})\end{array}$ & $\begin{array}{r}\text { CCB } \\
\mathrm{F}(\mathrm{t}) \\
\end{array}$ & $\begin{array}{r}\text { BOC } \\
\text { F (t) }\end{array}$ \\
\hline $\begin{array}{c}4.34^{*} \\
\left(-5.95^{* * 8}\right)\end{array}$ & $233.30^{* * 8}$ & $\begin{array}{c}2.29 \\
\left(-7.14^{* * 8}\right)\end{array}$ & $\begin{array}{c}12.57^{* * *} \\
\left(-8.71^{* * *}\right)\end{array}$ & $\begin{array}{c}25.47^{* * *} \\
\left(-10.20^{* * 8}\right)\end{array}$ & $\begin{array}{l}22.46^{* * *} \\
(-1.95)\end{array}$ \\
\hline $\begin{array}{c}1.40 \\
\left(-5.82^{* * 8}\right)\end{array}$ & $223.98^{* * 8}$ & $\begin{array}{c}3.48 \\
\left(-8.61^{* * 8}\right) \\
\end{array}$ & $\begin{array}{c}24.87^{* * *} \\
\left(-9.77^{* * *}\right)\end{array}$ & $\begin{array}{c}36.69^{* * *} \\
\left(-10.77^{* * *}\right)\end{array}$ & $\begin{array}{l}47.80^{* 8 *} \\
(-1.31)\end{array}$ \\
\hline $\begin{array}{c}0.49 \\
\left(-6.08^{* * 8}\right)\end{array}$ & $225.99^{* * 8}$ & $\begin{array}{c}0.30 \\
\left(-8.44^{* * 8}\right)\end{array}$ & $\begin{array}{c}8.79^{* *} \\
\left(-9.76^{* * *}\right)\end{array}$ & $\begin{array}{c}14.42^{* * *} \\
\left(-11.38^{* * *}\right)\end{array}$ & $\begin{array}{l}47.26^{* 8 *} \\
(-1.93)\end{array}$ \\
\hline $\begin{array}{c}6.81^{* *} \\
\left(-6.66^{* * 8}\right)\end{array}$ & $214.01^{* * 8}$ & $\begin{array}{c}5.49^{*} \\
\left(-9.75^{* * 8}\right) \\
\end{array}$ & $\begin{array}{c}0.51 \\
\left(-10.28^{* * 8}\right) \\
\end{array}$ & $\begin{array}{c}1.25 \\
\left(-11.59^{* * 8}\right) \\
\end{array}$ & $\begin{array}{c}41.34^{* * *} \\
\left(-3.14^{* *}\right)\end{array}$ \\
\hline $\begin{array}{c}3.60 \\
\left(-6.59^{* 88}\right) \\
\end{array}$ & $232.80^{* * 8}$ & $\begin{array}{c}1.46 \\
\left(-8.86^{* * 8}\right) \\
\end{array}$ & $\begin{array}{c}0.95 \\
\left(-10.44^{* * 8}\right) \\
\end{array}$ & $\begin{array}{c}3.53 \\
\left(-11.78^{* * 8}\right) \\
\end{array}$ & $\begin{array}{c}48.56^{* * *} \\
\left(-2.98^{* *}\right) \\
\end{array}$ \\
\hline $\begin{array}{c}4.24^{*} \\
\left(6.05^{* * *}\right) \\
\end{array}$ & $169.28^{* 28}$ & $\begin{array}{c}10.00^{* * *} \\
\left(7.51^{* * *}\right) \\
\end{array}$ & $\begin{array}{c}0.88 \\
\left(10.11^{* * *}\right) \\
\end{array}$ & $\begin{array}{c}2.35 \\
\left(10.64^{* * *}\right) \\
\end{array}$ & $\begin{array}{l}37.88^{* * 8 *} \\
\left(2.33^{*}\right) \\
\end{array}$ \\
\hline
\end{tabular}




\section{Conclusion and suggestion}

Online banking is an important response for commercial banks in the internet age. Governments, commercial banks, companies and scholars are actively involved in the study of relevant policies or issues. However, there are still few studies associated with people's behavior of online banking today, so the purpose of this paper is to explore people's behavior of online banking and its influencing factors, and to analyze the differences caused by people's gender, monthly income and the used platforms.

According to the literature review and the statistical results of the questionnaire survey, it is found that: people's behavior of online banking could be divided as amount and frequency, and they are defective for China. Thus, online banking still needs to develop by governments, commercial banks, companies and scholars. The online banking's financial advantage cognitions, perceived usefulness, platform convenience cognitions, and platform risk cognitions have significant influence on people's behavior. Therefore, the online banking policies or regulations of the government or commercial banks should consider the influencing factors like these.

People's gender and monthly income have a significant impact on people's behavior of online banking. Statisticians in commercial banks should conduct research on related topics based on people's gender and monthly income, and then develop differentiated marketing strategies for online banking. People's used platform should have an impact on people's behavior of online banking, so the marketing strategy about customer loyalty should be strengthen.

Based on the above findings, this paper suggests: commercial banks should strengthen the scope and scale of online banking. Its reason is that Chinese people have accustomed to the electronic payment model, but the habits of using online banking have not yet been established. Moreover, online banking should be the main development business of commercial banks. According to domestic and foreign literatures, online banking has become a survival mode for small and medium-sized commercial banks; even large banks are also developing online banking services actively. However, people's average frequency and amount of use by our people today is still tiny (see the statistical results of this article). The average frequency of use of respondents is 3.81 times/month, and the amount used is RMB 2,301.59. The paper suggests that the government should actively counsel small and medium-sized commercial banks to develop online banking services, in order to avoid bankruptcy during the period of market competition. The combination of online banking and wealth management services should also be developed actively to promote virtual banking.

Commercial banks should strengthen their customers' awareness of the advantages and reduce their doubts about defects of online banking. In turn, the frequency and amount would be increased. According to the statistics of the questionnaires, the influencing factors on people's behavior of online banking are all significant. Therefore, banks can promote the online banking's financial advantages, usefulness and convenience, combining with cross-industry cooperation through marketing strategies to increase customers' cognitions of online banking. To eliminate the risk of online banking, the paper suggests that commercial banks should strengthen the development of financial security technology required by online banking. The government should conduct relevant laws and regulations on the legal issues (such as risk issues) that may occur in this field.

Commercial banks should make differentiated marketing strategies for online banking customers to increase the amount and frequency. According to the statistics of the questionnaire, it is found that people's gender and monthly income significantly affect people's behavior of online banking. The paper suggests that there should be an online banking marketing strategy of tailor-made services for male or people with high income and increase the amount and frequency through the link among various types of platforms. 
The further research direction of this paper is the impact of occupation on people's behavior of online banking and its influencing factors. Nagabhushnam (2012) pointed out that the career of Indian customers is a significant factor in people's behavior of online banking.

\section{References}

[1] Ramsey, L. (2014), Internet Finance's Impact on Traditional Finance, The Journal of International Finance, 16(2): 31-49.

[2] Ozdemir, S. and Trott, P. (2009), Exploring the Adoption of a Service Innovation: A Study of Internet Banking Adopters and Non-adopters, Journal of Financial Services Marketing, 13(4): 284-299.

[3] Meyer, T. (2006), online Banking. What We Learn from Differences in Europe, in Deutsche Bank Research (Ed), E-Banking Snapshot. Deutsche Bank Research, Frankfurt and Ma.

[4] Hernandez, J. M. C. and Mazzon, J. A. (2007), Adoption of Internet Banking: Proposition Implementation of an Integrated Methodology Approach. International Journal of Bank Marketing, 25(2): 72-88.

[5] Sayar, C. and Wolfe, S. (2007), Internet Banking Market Performance: Turkey Versus the UK, International Journal of Bank Marketing, 25(3): 122-41.

[6] Analysys(2018) "China Internet Banking Market Quarterly Monitoring Report, First Quarter of 2018", Analysys International Group.

[7] Unyathanakorn, K. and Rompho, N. (2014), Factors Affecting Customer Satisfaction in online Banking Service, Journal of Marketing Development and Competitiveness, 8(2): 50-60.

[8] Mattila, M. and Karjaluoto, H. and Pento, T. (2003), Internet Banking Adoption among Mature Customers: Early Majority or Laggards? Journal of Service Marketing , 17(5): 514-528.

[9] Shen, R. (2015), Co-ordination Strategy between Commercial Banks and New Financial Institutions. Zhejiang Finance, (11): 4-8.

[10]Xing, J. (2001), Analysis of the Competitive Advantages of Internet Banking. Journal of Northwest Normal University (Social Science Edition), (02): 96-100.

[11]Flavian, C. and Guinaliu, M. Torres, E. (2006), How Bricks-and-Mortar Attributes Affect online Banking Adoption. International Journal of Bank Marketing, 24: 406-423.

[12]Lichtenstein, S. and Williamson, K. (2006), Understanding Consumer Adoption of Internet Banking: An interpretive study in the Australian Banking Context, Journal of Electronic Commerce Research, 7(2): 50.

[13]Aderonke, and Charles. (2010), An Empirical Investigation of the Level of Users' Acceptance of E-Banking in Nigeria. Journal of Internet Banking and Commerce, 15(1): 243-244.

[14]Liu, X. (2018), Research on the Risks and Supervision Countermeasures of Internet Banking[J].Modern Economic Information, (01): 300.

[15]Kim, C., Mirusmonov, M. and Lee, I. (2010), An Empirical Examination of Factors Influencing the Intention to Use Mobile Payment. Computers in Human Behavior, 26(3): 310-322.

[16]Sathye, M. (1999), Adoption of Internet Banking by Australian Consumers: An Empirical Investigation. International Journal of Bank Marketing, 17(7): 324-334. 